\title{
Cultivation Features Using Meteorological and Satellite Data from 2001 to 2010 in Dakhla Oasis, Egypt
}

\author{
Reiji Kimura1, Hiroshi Kato², Erina Iwasaki ${ }^{3}$ \\ ${ }^{1}$ Arid Land Research Center, Tottori University, Tottori, Japan \\ ${ }^{2}$ Hitotsubashi University, Tokyo, Japan \\ ${ }^{3}$ Faculty of Foreign Studies, Sophia University, Tokyo, Japan \\ Email: rkimura@alrc.tottori-u.ac.jp
}

Received 27 January 2015; accepted 13 February 2015; published 16 February 2015

Copyright (C) 2015 by authors and Scientific Research Publishing Inc.

This work is licensed under the Creative Commons Attribution International License (CC BY).

http://creativecommons.org/licenses/by/4.0/

(c) (i) Open Access

\begin{abstract}
The differences between the oasis region and the regions of the Nile delta and Nile valley in Egypt are due mainly to the regions' access to water. The oasis region depends on underground water, while the other regions rely on the Nile River. Numerous studies on cultivation in the Nile delta have been accumulated. However, few studies have addressed cultivation in the oasis region. This study examines cultivation throughout the government and local well districts using meteorological and satellite data from 2001 to 2010, and the interview in Rashda Village, Dakhla Oasis. Since the reference evapotranspiration $\left(E T_{0}\right)$ is lower in winter than in summer, cultivation in winter makes sense from the viewpoint of saving irrigation water. Evapotranspiration is highest in the order of date palm, rice paddy, winter wheat, and clover hay under sufficient wet conditions in Rashda Village. Cultivation features and water requirements were examined using the Normalized Difference Vegetation Index (NDVI) and Normalized Difference Water Index (NDWI). Results indicated a distinct difference in cultivation systems between the summer and winter seasons in the government well district. Water requirements for date palm in the local well district were 2.6 times those for winter plants in the government well district, using the accumulated NDWI value.
\end{abstract}

\section{Keywords}

Ground Water, Evapotranspiration, Normalized Difference Vegetation Index, Normalized Difference Water Index, Nubian Aquifer

\section{Introduction}

Agriculture in Egypt is strongly correlated to distance from the Nile River [1]. Figure 1 illustrates the distribution 


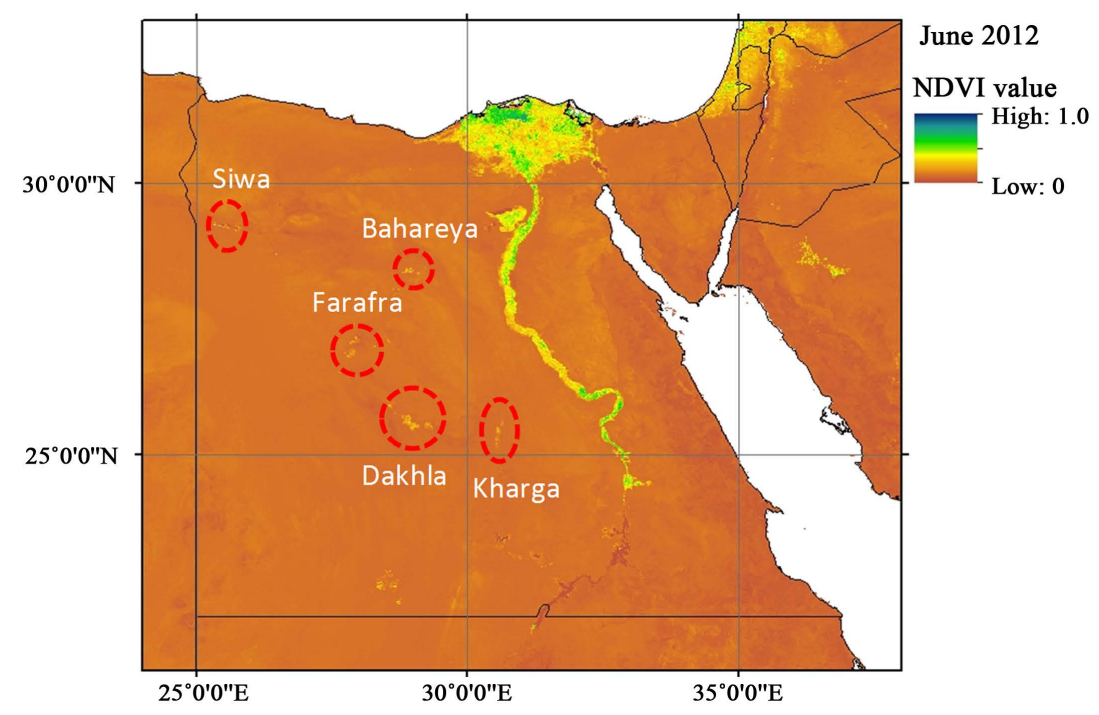

Figure 1. Distribution of NDVI, which indicates the vegetation amount, in Egypt on June 2012 from satellite data acquired by MODIS. Red circles indicate the locations of the oases.

of the Normalized Difference Vegetation Index (NDVI), which indicates vegetation amount, in Egypt in June 2012 using the MODe rate resolution Imaging Spectroradiometer (MODIS) satellite image data set (details will be discussed later). NDVI is high only along the Nile River and in the delta area, and not much vegetation can be seen far from the Nile River because of the hyperarid climate. However, some vegetation is found in the desert area far from the Nile River, although the NDVI there is little compared to that of the delta area. These oasis areas have been developed from time immemorial.

Cultivation in these oasis areas depends on fossil water (artesian ground water) originating from the Nubian aquifer [2]. Exploitable ground water resources are very large. However, because there is essentially no rainfall in this region, water is not rechargeable; therefore, the water wells are destined to dry up with time. The ground water levels of aquifers differ according to the underground geological conditions; thus, new water wells continue to be exploited, and old water wells and the land are abandoned. Cultivation in oasis areas is therefore vulnerable from the viewpoint of sustainable water use.

Traditional agriculture has focused on date palm in Dakhla oasis. Systematic agriculture has been conducted since the 1960s using a government well and rotating cultivation, as instructed by the government. In this study, we focus on cultivation features throughout the government and local well districts using meteorological and satellite data from 2001 to 2010, and the interview in Rashda Village, Dakhla Oasis.

\section{Study Site and Analysis Methods}

\subsection{Site Description and Analysis Method}

Dakhla, a major oasis in the Western Desert of Egypt (Figure 1), is located on low-level ground, at 0 to $200 \mathrm{~m}$ above sea level. The aridity index used by the United Nations Environment Program [3] indicates that this district lies in a hyperarid region, with annual rainfall of nearly $0 \mathrm{~mm}$. Consequently, the surrounding area is bare of vegetation, except for very isolated clumps of Acacia or Tamarix that survive on the shallow moisture held in blown sand, and moisture from dew, isolated showers, and frontal storms [4]. The climate of Dakhla is controlled mainly by the Harmattan, which is a hot wind resulting from high pressure in the Sahara. Although wind directions are mostly north, a slight westerly skewing of the maximum probably reflects topographic in draft of northern winds into the Dakhla depression [4].

Meteorological data between 2001 and 2010 sourced from National Climatic Data Center (NCDC) Climate Data Online of the Dakhla Meteorological Station (station number 624,320, 25.48 $\mathrm{N}, 29.0^{\circ} \mathrm{E}, 117 \mathrm{~m}$ ) was used to analyze the meteorological features and reference evapotranspiration $\left(E T_{0}\right)$ defined by [5]. Daily $E T_{0}\left(\mathrm{~m} \cdot \mathrm{md}^{-1}\right)$ as expressed by [5] is 


$$
E T_{0}=\frac{0.408 \Delta\left(R_{n}-G\right)+\gamma(900 / T) U\left(e_{s}-e_{a}\right)}{\Delta+\gamma(1+0.34 U)}
$$

where $\Delta$ is the slope vapor pressure curve $\left(\mathrm{kPa} \cdot{ }^{\circ} \mathrm{C}^{-1}\right), R_{n}$ is the net radiation $\left(\mathrm{MJ} \cdot \mathrm{m}^{-2} \cdot \mathrm{day}^{-1}\right), G$ is the soil heat flux $\left(\mathrm{MJ} \cdot \mathrm{m}^{-2} \cdot\right.$ day $\left.^{-1}\right), \gamma$ is the psychrometric constant $\left(\mathrm{kPa} \cdot{ }^{\circ} \mathrm{C}^{-1}\right), T$ is the air temperature $\left({ }^{\circ} \mathrm{C}\right), U$ is the wind speed $\left(\mathrm{m} \cdot \mathrm{s}^{-1}\right), e_{\mathrm{s}}$ is the saturation vapor pressure $(\mathrm{kPa})$, and $e_{a}$ is the actual vapor pressure $(\mathrm{kPa})$. The procedure for calculating $E T_{0}$ is described in detail by [5]. The effect of $G$ is ignored for actual daily calculations. For $R_{n}$ calculation, the data of sunshine duration is needed. Since it was not observed at the Dakhla Meteorological Station, we referred to the measured relative sunshine duration (ratio of actual sunshine duration to possible sunshine duration) for 1990 to 2005 at the Kharga Meteorological Station (station number 624,350, 25.45 $\mathrm{N}, 30.53^{\circ} \mathrm{E}, 73$ $\mathrm{m})$, which is $120 \mathrm{~km}$ from Dakhla [6]. The annual mean percentage of relative sunshine duration was high at $87 \%$ (minimum at $82 \%$ in January, maximum at $90 \%$ in June). The observational height of $U$ in Equation (1) is defined as $2 \mathrm{~m}$. Because the actual observational height is $10 \mathrm{~m}$, we converted the observed wind speed using following formula [5]:

$$
U_{2}=U_{z} \frac{4.87}{\ln (67.8 \cdot z-5.42)}
$$

where $U_{2}$ is the wind speed at $2 \mathrm{~m}\left(\mathrm{~m} \cdot \mathrm{s}^{-1}\right)$ and $U_{\mathrm{z}}$ is the observed wind speed at $z \mathrm{~m}\left(\mathrm{~m} \cdot \mathrm{s}^{-1}\right)$.

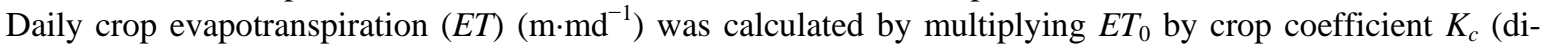
mensionless):

$$
E T=K_{c} \cdot E T_{0} .
$$

Table 1 lists the $K_{c}$ value [5] over each growth stage of the main cultivated crops in Rashda Village. Since these $K_{c}$ values are determined under typical irrigation management and soil wetting, ET in Equation (3) is assumed as the evapotranspiration for non-stressed conditions. The seasonal variation of $K_{c}$ was determined from the growing schedule using the interview (Table 1), the actual growth pattern using the NDVI, and the $K_{c}$ value in Table 1.

LANDSAT-5/TM and LANDSAT-7/ETM+ images were used to detect the amount of vegetation and water in the government and local well districts. We obtained 108 images during the analysis period between 2001 and 2010. NDVI provides a measure of the amount of vegetation on the land surface [7]. In general, higher NDVI values indicate greater amounts of vegetation. NDVI produces values of -1 to 1 . The negative values indicate the presence of water bodies (e.g., oceans, rivers, lakes, and snow). Small positive values indicate bare ground with little or no green vegetation, while values approaching 1 are a sign of lush green vegetation. [8] indicated that $0.05 \leq \mathrm{NDVI}<0.2$ is bare land or bare land surface with less vegetation, based on the [9]. The NDVI can be estimated from the reflectances of bands 3 and 4 using the following formula:

$$
\begin{gathered}
N D V I=\frac{\rho_{4}-\rho_{3}}{\rho_{4}+\rho_{3}} \\
\rho_{\lambda}=\frac{\pi \cdot L_{\lambda}}{E S U N_{\lambda} \cdot \cos \theta \cdot d_{r}}
\end{gathered}
$$

where $\rho_{4}$ and $\rho_{3}$ are the reflectances for bands 4 and $3, \lambda$ is the band number, $L_{\lambda}$ is the sensor observed radiance

Table 1. Cultivation schedule, crop coefficient value $\left(K_{c}\right)$ in the initial, mid-season and end-season periods, and evapotranspiration of main cultivated crops in Rashda.

\begin{tabular}{cccccc}
\hline Crop & Schedule & Kcini & Kcmid & Kcend & ET (mm) \\
\hline Winter wheat & Nov. to May & 0.70 & 1.15 & 0.40 & 687 \\
Clover hay (Berseem) & Nov. to May & 0.40 & 0.90 & 0.85 & 667 \\
Date palm & Through the year & 1.90 & 0.95 & 0.95 & 1689 \\
Rice paddy & Jun. to Oct. & 1.05 & 1.20 & 0.90 & 1016 \\
\hline
\end{tabular}


for band $\lambda\left(\mathrm{W} \cdot \mathrm{m}^{-2} \cdot \operatorname{ster}^{-1} \cdot \mu \mathrm{m}^{-1}\right), E S U N_{\lambda}$ is the mean solar exoatmospheric irradiance for band $\lambda\left(\mathrm{W} \cdot \mathrm{m}^{-2} \cdot \mathrm{ster}^{-1} \cdot \mu \mathrm{m}^{-1}\right), \theta$ is the solar incident angle normal to the surface, and $d_{r}$ is the inverse squared relative distance between the Earth and the Sun.

The Normalized Difference Water Index (NDWI) is a satellite-derived index acquired from the NIR and SWIR reflectances, and provides a measure of the amount of water in vegetation canopies [10]. NDWI gives a positive value for green vegetation and a negative one for dry vegetation. It is calculated using the following formula, which is the same as that used to determine NDVI:

$$
N D W I=\frac{\rho_{4}-\rho_{5}}{\rho_{4}+\rho_{5}}
$$

where $\rho_{5}$ is the reflectance for band 5 .

The government well district (area 70 ha, center location $25^{\circ} 35^{\prime} 35^{\prime \prime} \mathrm{N}, 28^{\circ} 55^{\prime} 17^{\prime \prime} \mathrm{E}, 97 \mathrm{~m}$ ) and the local well district (area 22 ha, center location $25^{\circ} 35^{\prime} 05^{\prime \prime} \mathrm{N}, 28^{\circ} 56^{\prime} 04 " \mathrm{E}, 99 \mathrm{~m}$ ) were classified polygonally using the image in Figure 2, and the averaged NDVI and NDWI values were calculated. Each of the 34 farmers in the government well district owned land in the North, South, and West sub-districts. Averaged NDVI and NDWI values were calculated for each sub-district in the government well district and the local well district. Bands 3, 4, and 5 had a resolution of $30 \mathrm{~m}$.

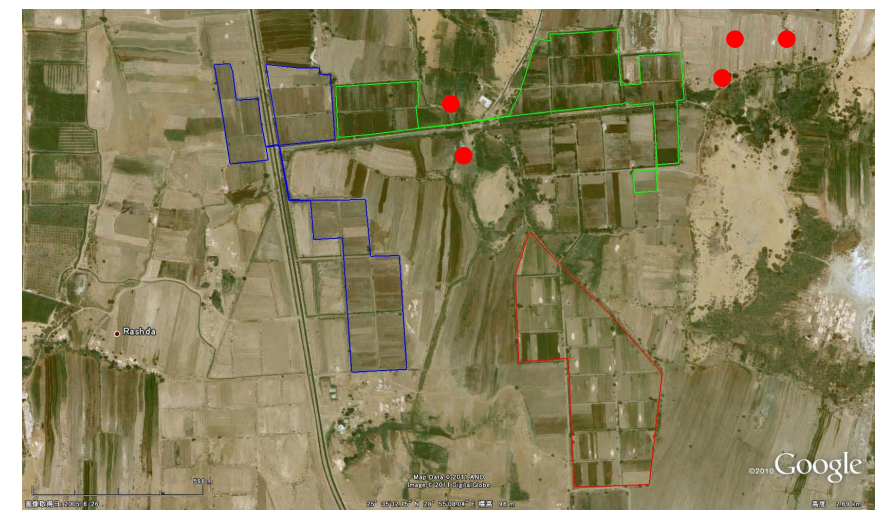

(a)

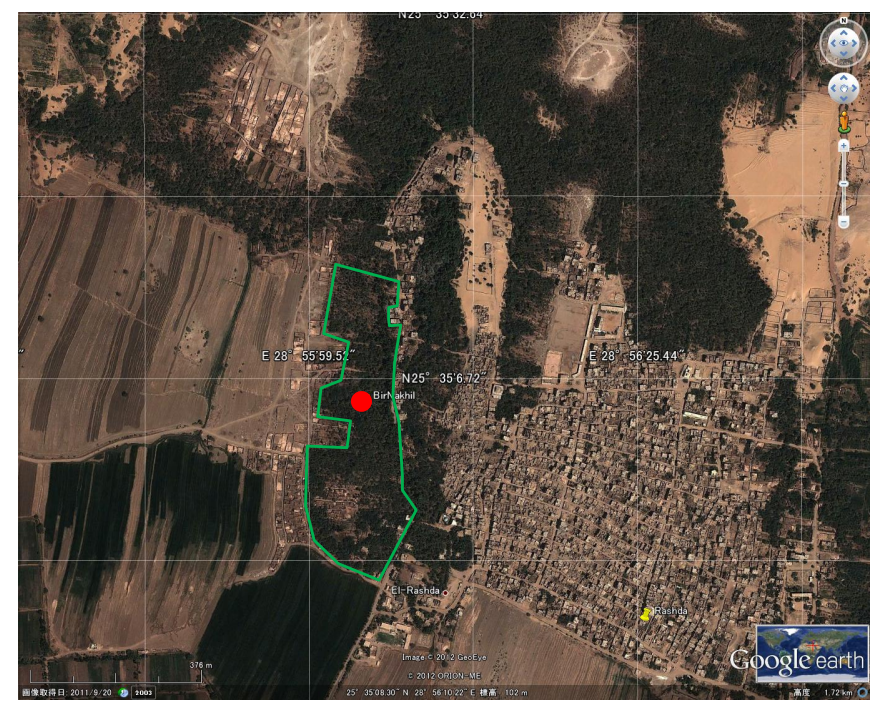

(b)

Figure 2. The North (green), South (red), and West (blue) sub-districts in the government well district (a) and the local well district (b). Red circles indicate the locations of the wells. These maps were made using Google map. 
We also used the MODIS-Terra monthly 1 km NDVI product (MODIS/Aqua Vegetation Indices Monthly L3 Global $1 \mathrm{~km}$ SIN Grid V005*, http://modis.gsfc.nasa.gov/) to clarify the spatial distribution of vegetation amount in Egypt (Figure 1).

\subsection{Irrigation and Cultivation System in the Government and Local Well Districts in Rashda Village}

The water source in Dakhla Oasis and throughout the Western Desert is the Nubian sandstone aquifer, which is the world's largest fossil water aquifer system. Therefore, the irrigation and cultivation system in Dakhla Oasis differs from that in the Nile delta and valley, which depends completely on the Nile River as its water source. The ground water of the Nubian aquifer was recharged 14,000 to 30,000 years ago, and the last rainy season related to the recharge occurred 8000 years ago, according to isotopic analysis [2]. Currently, rainfall provides little recharge water to the recharge area (northwest part of Sudan and Uwein at Upland located at the boundary of Egypt, Libya, and Sudan), so the irrigation water in Dakhla Oasis is mainly fossil water having ancient roots [11].

In Dakhla Oasis, the underground water is extracted using a well. The estimated number of wells and springs is 70 in Rashda Village. [1] provided detailed information on these wells. Government wells are utilized by the government (Ministry of Irrigation) and are owned and managed by the Ministry of Irrigation. They generally have a depth of $1200 \mathrm{~m}$ and are supposed to last 50 years. There are 12 wells of this type in Rashda. Local wells are artesian wells that are dug in the traditional way, and are owned and managed collectively by local cultivators. Their depth is usually $85 \mathrm{~m}$ or less. The well leader maintains a list of cultivators who have access to the water source. The water source is supposed to last 20 years. There are 29 wells of this type in Rashda. Figure 2(a) indicates the locations of five government wells, and Figure 2(b) indicates that of one local well.

Irrigation water flows from wells through main and branch canals into parcels of cultivated land through the main and branch distributors. Irrigation is then managed according to the basin irrigation system in both government and local well districts. The interview indicates that in the government well district, $22 \mathrm{~m}^{3}$ of water is irrigated to each feddan ( 1 feddan $=0.42$ ha) once every 12 days from October to April, and $40 \mathrm{~m}^{3}$ of water is irrigated to each feddan once every 12 days from May to September. In the local well district, $30 \mathrm{~m}^{3}$ of water is irrigated to each feddan once every 10 days through the year.

The prevailing crops in the government well district are wheat or clover hay (berseem) in winter, and rice in summer under the following rotation:

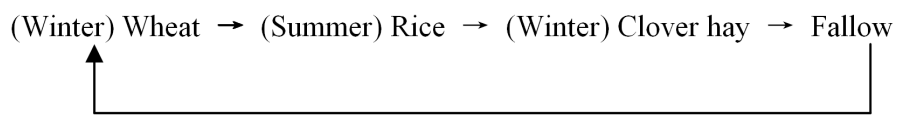

Dates are generally produced on land associated with the local well. The land associated with governmental wells does not have palm trees. Water management, crop types grown, and their rotation are decided by the Department of Agriculture in the government well district. However, this rule is not strictly applied in areas irrigated by local wells.

\section{Results and Discussion}

\subsection{Meteorological Features in Dakhla Oasis}

Figure 3 indicates the average seasonal variation of daily average temperature, wind speed, vapor pressure, and daily $E T_{0}$ from 2001 to 2010 . The annual daily average temperature was $24.4^{\circ} \mathrm{C}$ (highest $34.9^{\circ} \mathrm{C}$ in July and lowest $13.0^{\circ} \mathrm{C}$ in January). The annual average daily maximum temperature was $32.8^{\circ} \mathrm{C}$ (highest $42.5^{\circ} \mathrm{C}$ in July and lowest $20.9^{\circ} \mathrm{C}$ in January). The annual average daily minimum temperature was $16.0^{\circ} \mathrm{C}$ (highest $26.4^{\circ} \mathrm{C}$ in July and lowest $4.6^{\circ} \mathrm{C}$ in January). The annual average daily vapor pressure was $1.1 \mathrm{kPa}$ (highest $1.5 \mathrm{kPa}$ in August and lowest $0.7 \mathrm{kPa}$ in February). Dakhla is comparatively humid because irrigation farming is widespread. The annual daily average wind speed was $1.9 \mathrm{~m} \cdot \mathrm{s}^{-1}$ (strongest $2.9 \mathrm{~m} \cdot \mathrm{s}^{-1}$ in April and weakest $1.0 \mathrm{~m} \cdot \mathrm{s}^{-1}$ in November).

\section{2. $E T_{0}$ and Crop Evapotranspiration Using Meteorological Data}

The average seasonal variation of daily $E T_{0}$ from 2001 to 2010 is indicated in Figure 3. The annual average $E T_{0}$ 

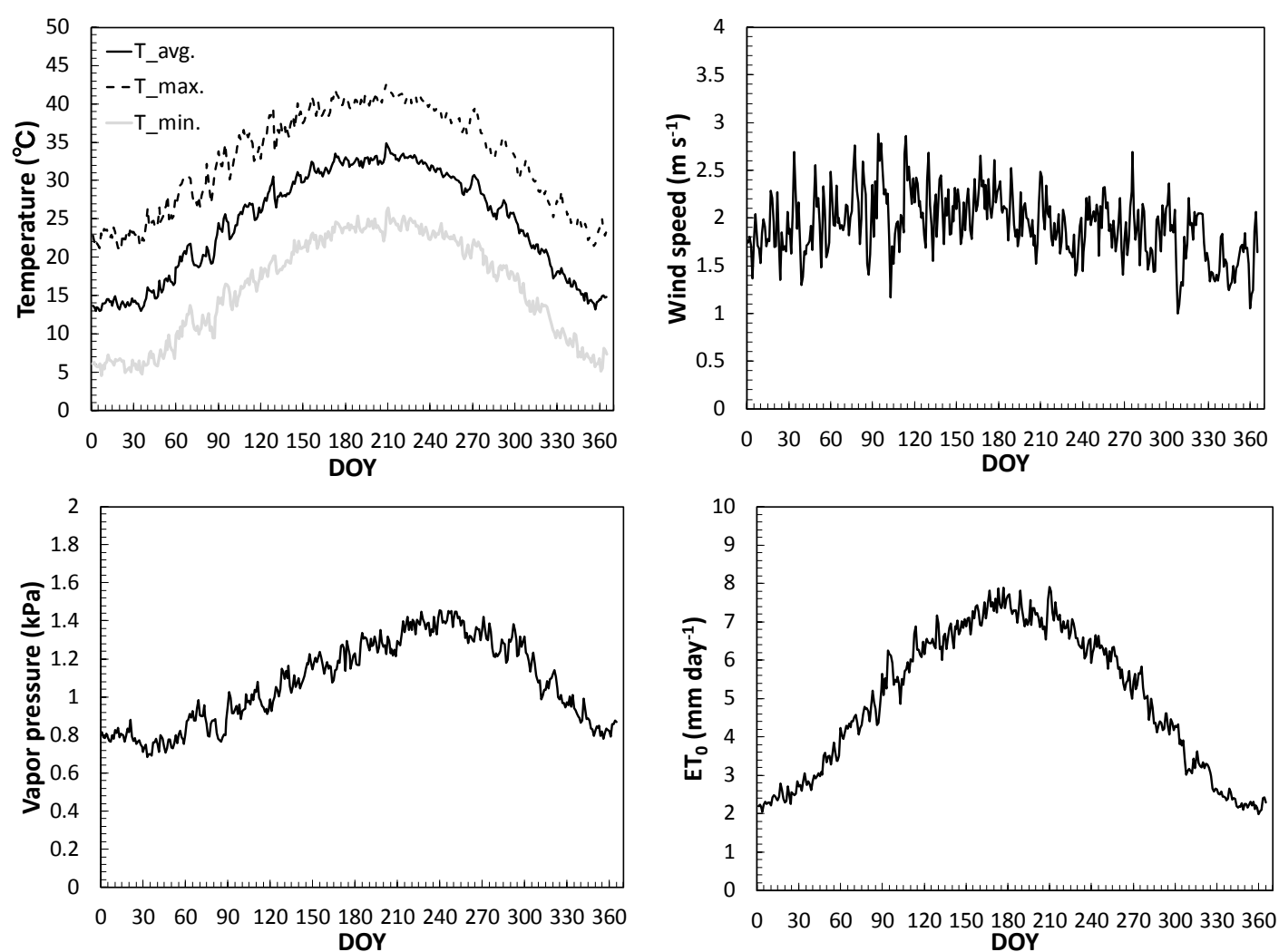

Figure 3. Seasonal variation of daily averaged temperature, daily maximum temperature, daily minimum temperature, daily averaged wind speed, daily averaged vapor pressure, and daily averaged $E T_{0}$ between 2001 and 2010.

was $5.0 \mathrm{~m} \cdot \mathrm{md}^{-1}$ (greatest $7.9 \mathrm{~m} \cdot \mathrm{md}^{-1}$ in July and least $2.0 \mathrm{~m} \cdot \mathrm{md}^{-1}$ in December). The annual $E T_{0}$ was 1816 $\mathrm{m} \cdot \mathrm{my}^{-1}$. If actual sunshine duration was assumed to be the same as possible sunshine duration, annual $E T_{0}$ was $1884 \mathrm{~m} \cdot \mathrm{my}^{-1}$. The difference was $68 \mathrm{~m} \cdot \mathrm{my}^{-1}\left(0.19 \mathrm{~m} \cdot \mathrm{md}^{-1}\right)$, which is within observational error [12]. Thus, possible sunshine duration can be used to calculate $E T_{0}$ in Dakhla Oasis. Since $E T_{0}$ in winter is less than in summer, cultivation in winter makes sense from the viewpoint of water saving, as discussed in the next section.

Evapotranspiration for each crop during the growing season is indicated in Table 1. It should be noted that this evapotranspiration was calculated assuming sufficient wet conditions; therefore, actual evapotranspiration will be less than these values. Under the meteorological conditions in Dakhla, water requirements are highest for date palm, and second highest for rice paddy. According to the interview, farmers preferred to grow wheat or clover hay rather than date palm in government well districts because the cultivation of date palm requires an abundance of water. However, date palm is still cultivated in local well districts. Water demand for winter wheat is comparatively low. However, because most nutrients in the soil are consumed in its cultivation, a fallow period and clover hay cultivation are necessary after wheat production to recover land conditions. It is noteworthy that water requirements for winter wheat are almost the same as for clover hay.

\subsection{Seasonal Variation of NDVI for Government and Local Well Districts}

Figure 4 indicates the seasonal NDVI variation (date palm) for each sub-district in the government and local well districts between 2001 and 2010. In Figure 5, the solid line represents a sixth-order polynomial equation, and four polynomial lines meet. In the government well district, the NDVI value reached maximum (0.6) in mid-February and decreased drastically until the end of May. Although the NDVI value decreased in the order of South, North, and West sub-districts during the winter season (November to May), their differences were small. A significant change in NDVI can be seen among the sub-districts during the summer season (June to October). After harvesting of winter plants (winter wheat or clover hay), some crops (e.g., rice) were planted and cultivated from the beginning of November in the South sub-district, although the scale of cultivation was 

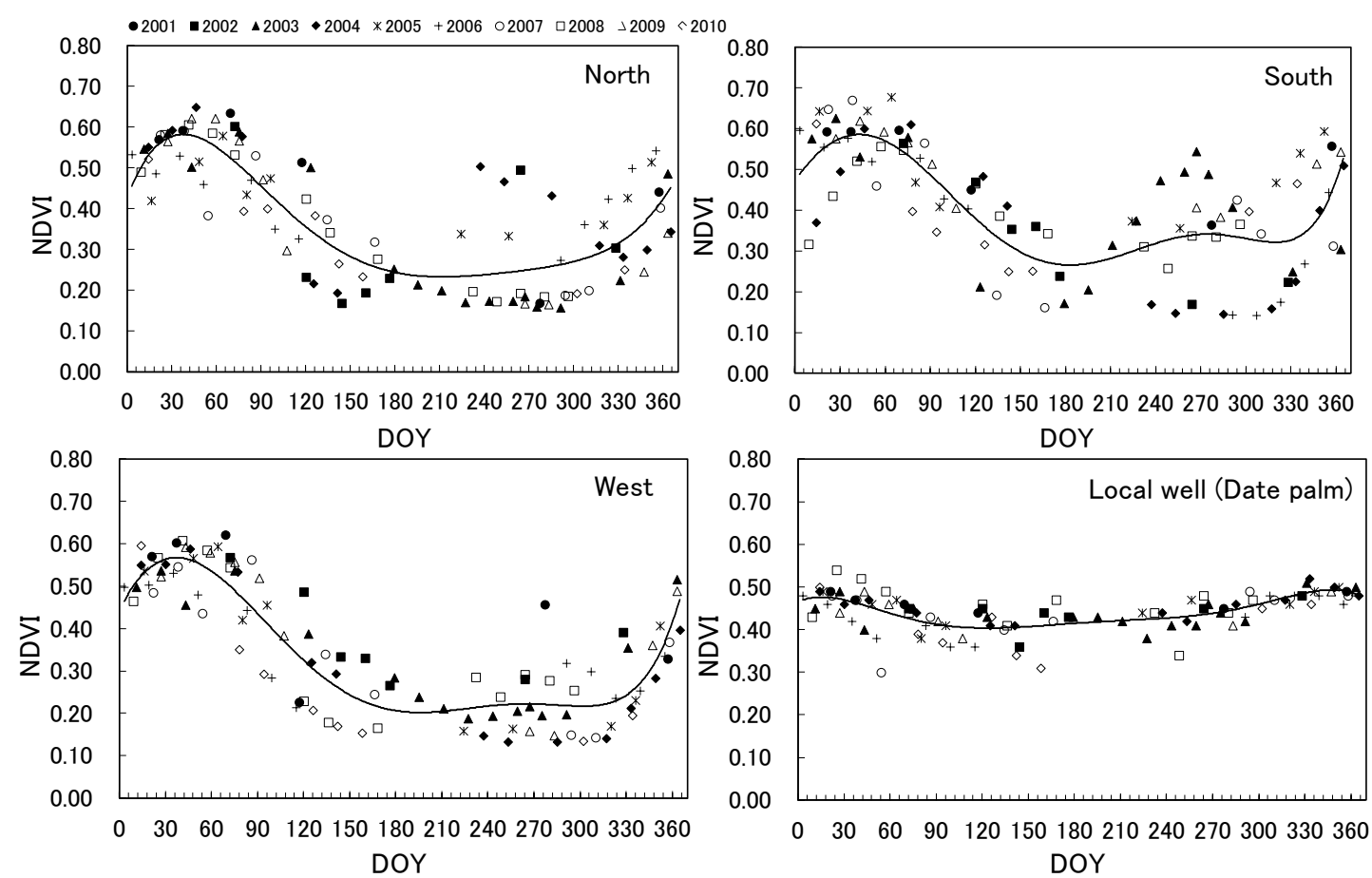

Figure 4. Seasonal variation in the NDVI for each sub-district of the government well district and the local well district between 2001 and 2010. The solid line indicates a sixth-order polynomial equation.

small compared to that of the winter season; however, the land remained fallow in the North and West sub-districts most years (Figure 4). Here, the fallow period was defined as when the NDVI was below 0.2 and NDWI was below 0, as discussed in Section 2.1. The high irrigation water volume required for cultivation in the summer climate means that fallow or small-scale cultivation is more suitable for Rashda Village during the summer from the viewpoint of water saving. Additionally, the government regulates rice paddy cultivation, based on the amount of water available for irrigation in the summer, under current irrigation laws. Such a rotation system in the government well districts could be confirmed even in the interview.

The NDVI value of date palm in the local well district was almost constant. However, a slight increase began in May and reached its maximum (0.5) in December. According to the interview, the date palm harvesting period was from September to November, and the average yield was $120 \mathrm{~kg}$ per tree (Figure 5).

\subsection{Seasonal Variation of NDWI for Government and Local Well Districts}

Figure 6 indicates the seasonal NDWI variation for each sub-district in the government well district and the local well district (date palm) between 2001 and 2010. In Figure 7, the solid line represents a sixth-order polynomial equation, and four polynomial lines. The seasonal variation trend of NDWI was similar to that of NDVI. The NDWI value of date palm was low in summer and began to increase toward the harvesting period. Since the NDWI provides a measure of the water amount in vegetation canopies, a low NDWI value might indicate water stress conditions for date palm in summer. The irrigation amount was constant through the year in the local well district ( $30 \mathrm{~m}^{3}$ of water irrigated to each feddan once every 10 days). The irrigation amount might be low for date palm in summer, when evapotranspiration requirements are large.

If the accumulated day-to-day NDWI value is assumed to be the total water requirement for each crop, differences in water requirements among crops can be estimated from the satellite data only. Figure 7 indicates that the accumulated NDWI was 109 for date palm in the local well district, and 42 for winter plants (winter wheat or clover hay) in the government well district, based on the averages of the North (42), South (45), and West (38) sub-districts during the winter season (November to May). Accumulated NDWI of date palm was 2.6 times that of winter plants. The given irrigation amounts were $257 \mathrm{~mm}$ for date palm and $102 \mathrm{~mm}$ for winter plants according to the interview; thus, irrigation amounts for date palm were 2.5 times those for winter plants. Table 1 also indicates that evapotranspiration of date palm was 2.5 times that of winter plants (average of winter 


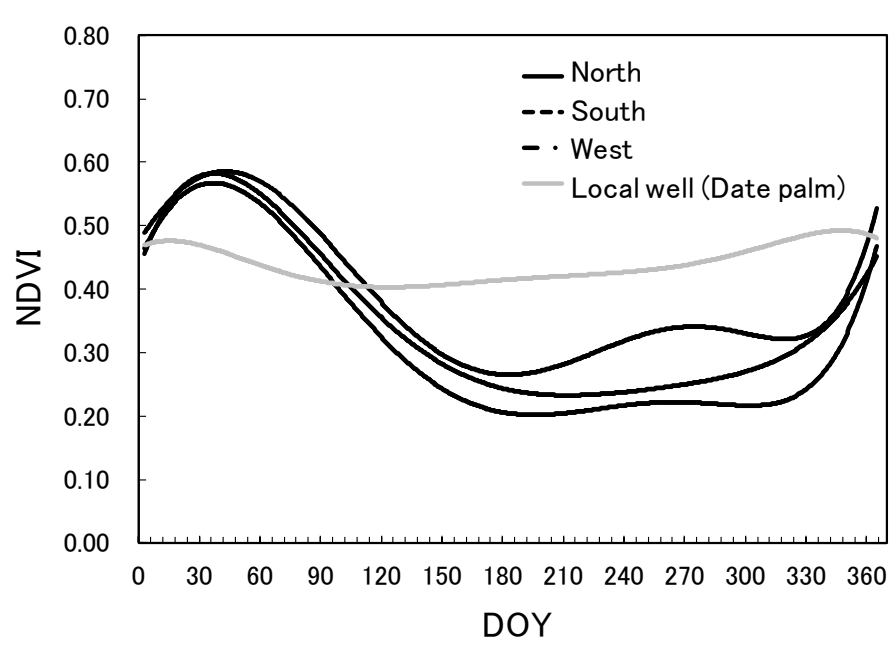

Figure 5. Seasonal variation in the NDVI using a sixth-order polynomial equation (indicated in Figure 4).
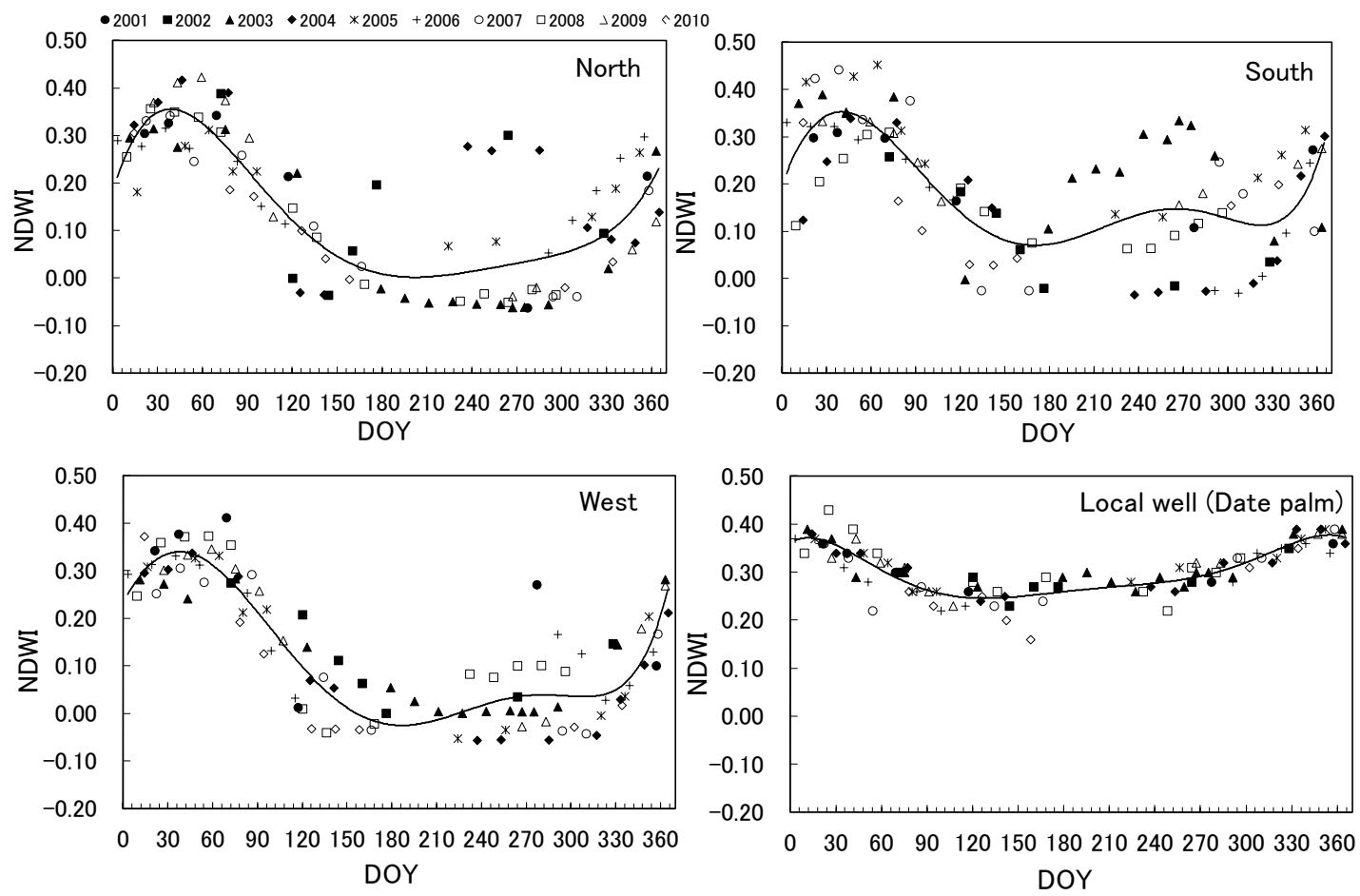

Figure 6. Seasonal variation in the NDWI for each sub-district of the government well district and the local well district between 2001 and 2010. The solid line indicates a sixth-order polynomial equation.

wheat and clover hay). It should be noted that this evapotranspiration was calculated assuming sufficient wet conditions; thus, actual evapotranspiration will be less than these values. Actually, irrigation amounts were much smaller than the calculated evapotranspiration in Table 1. These results may indicate the possible use of NDWI to detect differences in water requirements among crops. It will be important to compare the accumulated NDWI with actual evapotranspiration for future development of this concept.

\section{Conclusions}

Dakhla Oasis is located in the heart of the western desert in Egypt, $190 \mathrm{~km}$ west of Kharga Oasis. It contains highly fertile land and is rich in water, and it supports a higher population than Kharga Oasis. The Dakhla 


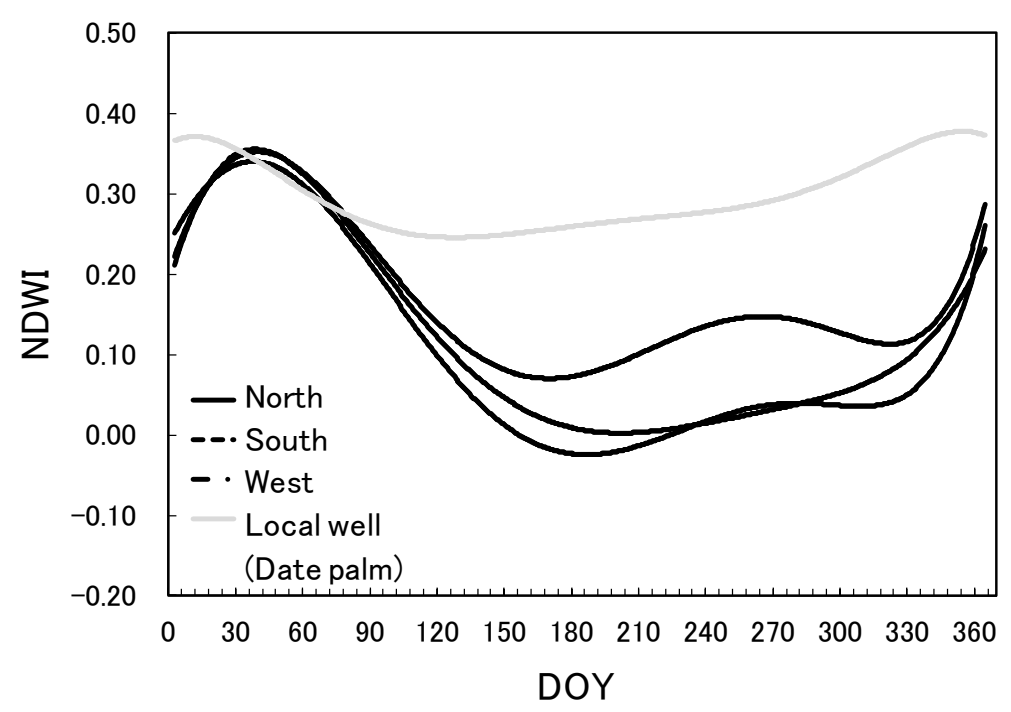

Figure 7. Seasonal variation in the NDWI using a sixth-order polynomial equation (indicated in Figure 6).

depression extends $155 \mathrm{~km}$ in the east-west direction. The area of the oasis that is suitable for agriculture is 155 $\mathrm{km}$ long and $60 \mathrm{~km}$ wide. In 2012, the number of wells increased 30\% compared to that in 2008. In recent years, irrigation farming has spread significantly in Dakhla Oasis. To extend the use of the limited groundwater resources, efficient irrigation farming is crucial.

This study focuses on cultivation features throughout the government and local well districts using the meteorological and satellite data from 2001 to 2010, and the interview in Rashda Village, Dakhla Oasis. It is one of a limited number of interdisciplinary studies involving the natural and social sciences, and will contribute to fill the lack of research on the cultivation features in the oasis region.

1) Since solar radiation and temperature are suitable for crop production, cultivation intensity depends on available groundwater in Dakhla. Since $E T_{0}$ in winter is less than in summer, cultivation in winter makes sense from the viewpoint of water saving.

2) Evapotranspiration is highest in the order of date palm, rice paddy, winter wheat, and clover hay under sufficient wet conditions in Rashda Village.

3) Approaches to detect cultivation features and water requirements were examined using NDVI and NDWI for the government and local well districts in Rashda Village. There was a distinct difference in cultivation systems between the summer and winter seasons in the government well district. Fallow or small-scale cultivation was applied in summer because of the high evapotranspiration demand and irrigation water saving. Water requirements for date palm were 2.6 times those for winter plants (winter wheat or clover hay) using the accumulated day-to-day NDWI value.

Our analysis has the following limitations.

1) Data on solar radiation were lacking in Dakhla Oasis. The western desert of Egypt was dominated by high pressure on the synoptic scale (2000 to 10,000 km) throughout the year. Thus, we assumed that the solar radiation condition in Dakhla Oasis was similar to that in Kharga Oasis $120 \mathrm{~km}$ from Dakhla Oasis.

2) Actual evapotranspiration data on each crop were not obtained. The proposed method to detect the water requirements using NDWI should be verified using the actual observed data of evapotranspiration for future development.

However, the observation system will be expensive and difficult to establish for a variety of reasons. Data obtained by satellite and the interview used in this study will also become a useful tool for analyzing cultivation features in arid regions, including the oasis area in Egypt.

\section{References}

[1] Kato, H., Iwasaki, E., Nagasawa, E., Anyoji, H., Matsuoka, N. and Kimura, R. (2010) Rashda: System of Irrigation and Cultivation in a Village in Dakhla Oasis. Mediterranean World, 20, 1-45. 
[2] Dabous, A.A. and Osmond, J.K. (2001) Uranium Isotopic Study of Artesian and Pluvial Contributions to the Nubian Aquifer, Western Desert, Egypt. Journal of Hydrology, 243, 242-253.

http://dx.doi.org/10.1016/S0022-1694(00)00417-0

[3] UNEP (1997) World Atlas of Desertification. Arnold, London.

[4] Brookes, I.A. (2001) Aeolian Erosional Lineations in the Libyan Desert, Dakhla Region, Egypt. Geomorphology, 39, 189-209. http://dx.doi.org/10.1016/S0169-555X(01)00026-5

[5] Allen, R.G., Pereira, L.S., Raes, D. and Smith, M. (1998) Crop Evapotranspiration: Guidelines for Computing Crop Water Requirements. FAO, Rome.

[6] Robaa, S.M. (2008) Evaluation of Sunshine Duration from Cloud Data in Egypt. Energy, 33, 785-795. http://dx.doi.org/10.1016/j.energy.2007.12.001

[7] Rouse, J.W., Haas, R.H., Schell, J.A. and Deering, D.W. (1974) Monitoring Vegetation Systems in the Great Plains with ERTS. Third ERTS-1 Symposium NASA, NASA SP-351, Washington DC, 309-317.

[8] Kimura, R. (2012) Effect of the Strong Wind and Land Cover in Dust Source Regions on the Asian Dust Event over Japan from 2000 to 2011. SOLA, 8, 77-80. http://dx.doi.org/10.2151/sola.2012-020

[9] ArcGIS Resource Center (2011) NDVI Function. http://resources.arcgis.com

[10] Gao, B.C. (1996) NDWI-A Normalized Difference Water Index for Remote Sensing of Vegetation Liquid Water from Space. Remote Sensing of Environment, 58, 257-266. http://dx.doi.org/10.1016/S0034-4257(96)00067-3

[11] Nada, A.A. (1995) Evaluation of Environmental Isotopic and Salinar Composition of Groundwater in Oases of the Western Desert, Egypt. Isotopes in Environmental and Health Studies, 31, 117-124. http://dx.doi.org/10.1080/10256019508036257

[12] Kondo, J. (1994) Meteorology of the Water Environment-Water and Heat Balance of the Earth’s Surface. Asakura, Tokyo. 
Scientific Research Publishing (SCIRP) is one of the largest Open Access journal publishers. It is currently publishing more than 200 open access, online, peer-reviewed journals covering a wide range of academic disciplines. SCIRP serves the worldwide academic communities and contributes to the progress and application of science with its publication.

Other selected journals from SCIRP are listed as below. Submit your manuscript to us via either submit@scirp.org or Online Submission Portal.
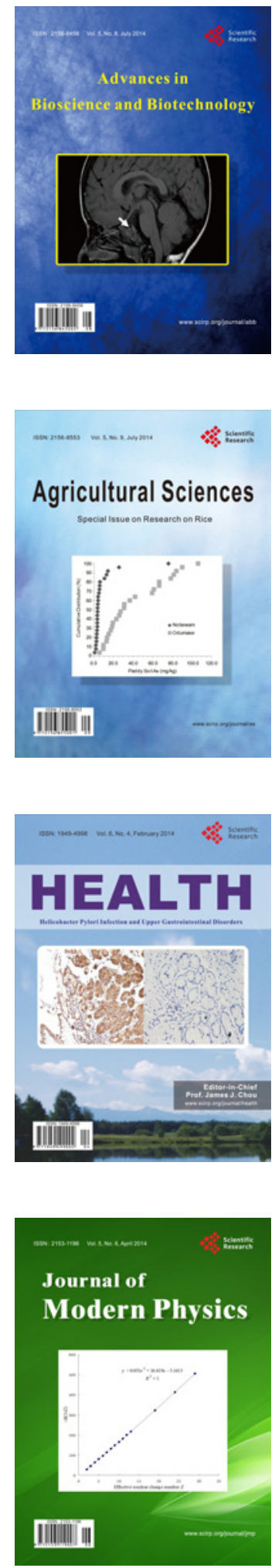
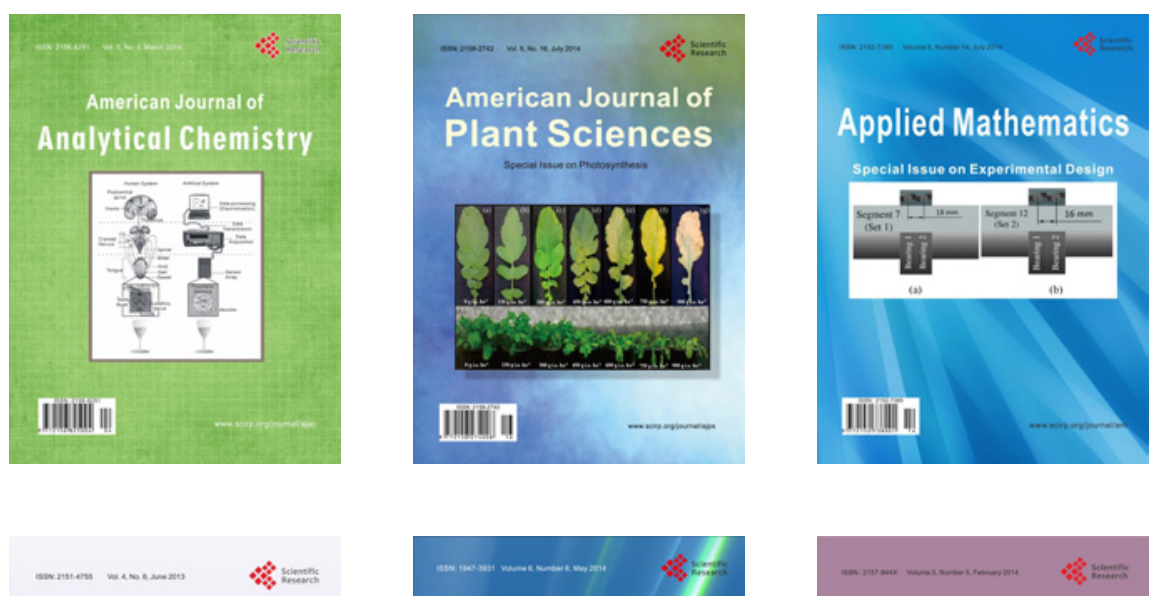

Creative Education
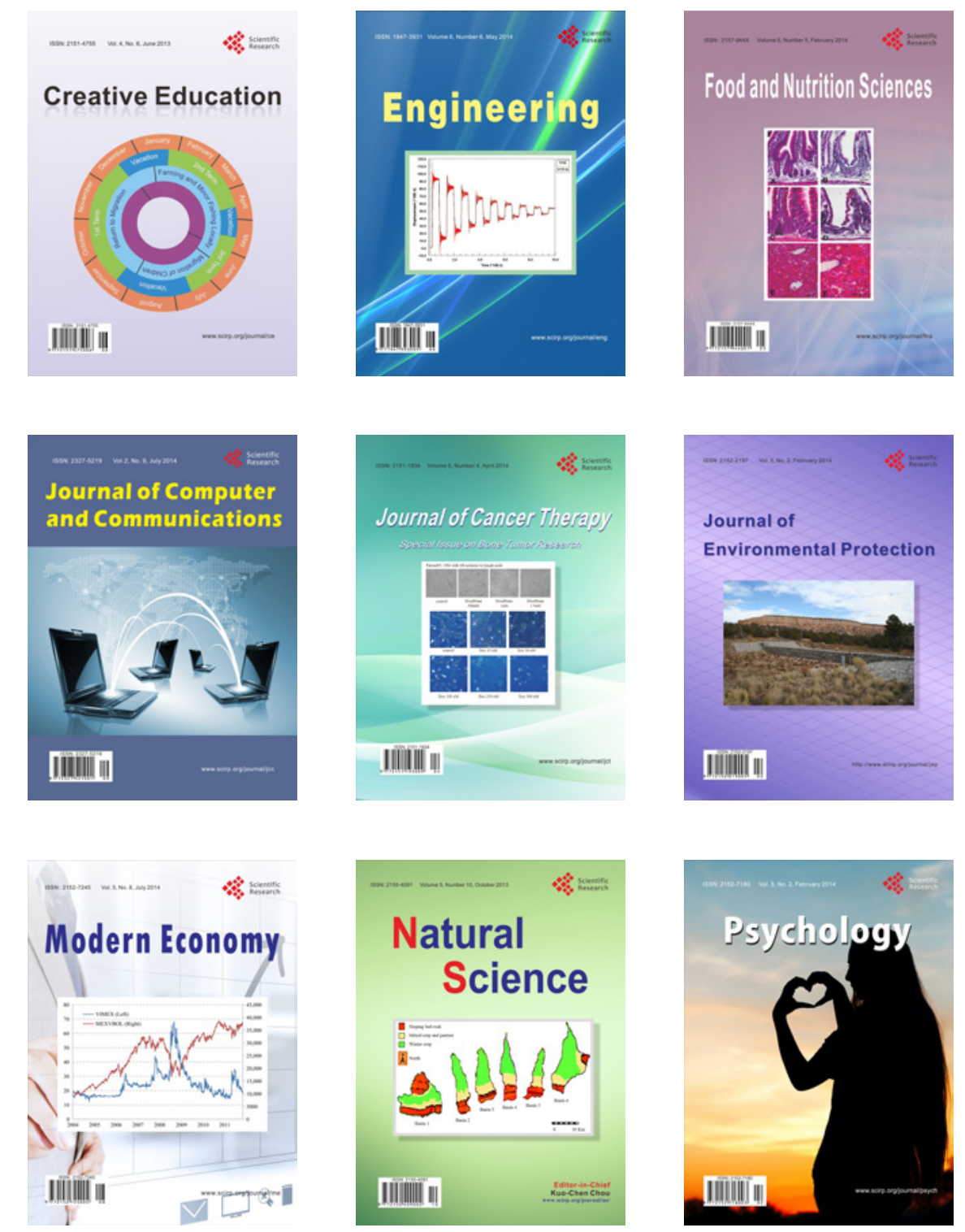